\title{
Electron Microscopic Study of Measles Virus Infection: Unusual Antibody-Triggered Redistribution of Antigens on Giant Cells
}

\author{
Hooghe-Peters E L, Rentier B, Dubois-Dalcq M \\ Infectious Diseases Branch, National Institute of Neurological and Communicative Disorders and
Stroke, National Institutes of Health, Bethesda, Maryland 20014
}

Vero cells infected with measles virus fuse to form multinucleated cells which incorporated virusspecific antigens in their membrane. The distribution of these antigens was analyzed after a brief treatment with human anti-measles immunoglobulin G, using autoradiography and immunoperoxidase labeling combined with transmission and scanning electron microscopy. Virus-specific antigens were distributed over the entire surface of giant cells treated at $4^{\circ} \mathrm{C}$ with human anti-measles immunoglobulin $\mathrm{G}$ and labeled Protein A. When cells were shifted to $37^{\circ} \mathrm{C}$, labeled antigen-antibody complexes were redistributed in two stages. Patch formation occurred in 5 to 15 min. Later, antigenantibody complexes became concentrated in a paracentral "ring" rather than typical caps. Patch formation occurred in the presence of metabolic inhibitors, whereas ring formation was inhibited by metabolic inhibitors. These rings contained membrane folds, villi, and viral buds, whereas the rest of the membrane was smooth. In addition, shedding, endocytosis of antigen-antibody complexes, and reexpression of antigens were observed. Antibodies to nonviral membrane antigens induced the same pattern of redistribution. Infected cells treated with anti-measles Fab' fragments maintained a homogeneous distribution of label throughout the experiments. In conclusion, intact immunoglobulins, but not Fab' fragments, were able to induce a dramatic redistribution of viral antigen on the membrane of giant cells infected with measles virus.

In a previous paper (20), we reported the results of studies on structural events related to syncytium formation in the course of measles virus infection. Our data suggest that syncytia are the sites of defective formation of virus, that hemadsorption is an excellent marker for measles virus-induced cell fusion, and that binding sites for erythrocytes move centripetally as fusion progresses. We now describe the interactions between antiviral antibodies and the surface of giant cells formed as a result of infection with measles virus. We have also investigated the structural events occurring in antibodydependent lymphocyte killing of measles virus-infected cells (Rentier et al., manuscript in preparation). The aim of these electron microscopic studies is to analyze the in situ process of fusion and the interactions between the immune system and measles virus-infected cells.

Binding of divalent antibody molecules to surface membrane antigens may induce topographic rearrangements of antigen-antibody $(\mathrm{Ag}-\mathrm{Ab})$ complexes. Ag-Ab complexes first form discrete aggregates (patches) separated by membrane areas depleted of these complexes. This essentially diffusional membrane movement is followed by capping, a metabolically dependent process consisting of the migration of the surface components toward one pole of the cell $(2,12,25)$. Ag-Ab complexes disappear from the cell surface by pinocytosis in the cap area or by the release of plasma membrane antigen into the medium (shedding). Another phenomenon possibly related to capping and clearance of a given antigen is called "antigenic modulation": cells may become insensitive to antibody and complement-mediated lysis even if no significant loss of antigen from the membrane has occurred $(2,10,16)$.

Patching and capping of viral antigens have been observed in avian tumor virus-infected fibroblasts (18) and in HeLa cells infected with influenza and measles viruses after treatment with antisera against the respective virus $(9,11,17,23)$. Antibody-triggered membrane changes occurring in measles virusinduced giant cells have not yet been analyzed, although giant cell formation appears critical for spreading of measles virus infection in some nonproductive systems. Therefore, we have studied the effect of a brief antibody treatment on the distribution and expression of viral and nonviral antigens on the surface of these giant cells. Syncytia were treated in situ to preserve their surface integrity. Ag-Ab complexes were detected with peroxi-dase-labeled or iodinated Protein A (PrA). The redistribution and fate of Ag-Ab complexes were followed for $24 \mathrm{~h}$ by autoradiography as well as by scanning and transmission electron microscopy (SEM and TEM, respectively) combined with immunoperoxidase labeling. Divalent antibody triggered a series of structural events which appear characteristic of these virus-induced giant cells. 
(This study was presented in part at the 17th Annual Meeting of the American Society for Cell Biology, San Diego, Calif., 15-18 November 1977.)

\section{Materials and methods}

Cells and viruses. Techniques for growing Vero cell monolayers and infecting them with measles virus, as well as the origin of this virus, have been described in detail in a previous paper (20). Experiments were started 3 days after infection when multinucleated cells with a diameter of approximately $800 \mu \mathrm{m}$ were present.

Antisera. Sera were obtained from a healthy human donor and from a patient convalescing from acute measles virus infection. Their measles antibody titers were 1:64 (donor no. 1) and 1:256 (donor no. 2), respectively, as measured by inhibition of hemagglutination $(26,27)$. The first serum did not react with uninfected Vero cells, whereas the second serum had to be absorbed with uninfected Vero cells to remove nonspecific binding. Immunoglobulin $\mathrm{G}(\mathrm{IgG})$ fractions were purified from these sera by precipitation with 50\% ammonium sulfate, followed by DEAE-cellulose chromatography (28). Fab' fragments were prepared from the IgG of donor no. 1 by reduction, alkylation, and pepsin digestion, followed by chromatography on Sephadex G-100 (21). F( $\left.a b^{\prime}\right)_{2}$ fragments were prepared from the IgG of donor no. 2 by pepsin digestion of nonreduced antibodies (14). For the sake of clarity, $\operatorname{IgG~F}\left(\mathrm{ab}^{\prime}\right)_{2}$, and Fab' preparations containing anti-measles activity will be referred to as "anti-measles reagents." A control serum was obtained from a 6-month-old child. This serum did not have detectable measles antibody as measured by the fluorescent-antibody assay. Since only small quantities of this serum were available, this material was used as whole undiluted serum, not as purified IgG. This serum did not react with Vero cells.

A rabbit serum against Vero cells was prepared by Microbiological Associates, Bethesda, Md, and used undiluted.

Detection of Ag-Ab complexes. Purified PrA from Staphylococcus aureus (Pharmacia Fine Chemicals, Inc., Piscataway, N.J.) is a tetrameric protein that binds the Fc portion of IgG from many species, including humans and goats. PrA was coupled to horseradish peroxidase (3) or labeled with ${ }^{125} \mathrm{I}$ by the chloramine-T method (8). The radioactive PrA had a specific activity of $5 \mathrm{mCi} / \mathrm{mg}$. Labeled PrA was used to detect cell-bound IgG. Cells treated with anti-measles Fab' or F(ab') ${ }_{2}$ fragments were first incubated with goat IgG directed against human Fab fragment (Cappel Laboratories, Inc., Dowingtown, Pa.). Perox-idase-labeled PrA was then used to detect these goat anti-Fab IgG.

Other chemicals. Sodium azide, 2,4-dinitrophenol, concanavalin A (ConA), vinblastine sulfate, and colchicine were purchased from Sigma Chemical Co., St. Louis, Mo. Concentrated stock solutions of each compound were prepared in minimum essential medium just before use. Final concentrations used in this study were as follows: $\mathrm{NaN}_{3}, 10^{-2} \mathrm{M}$; vinblastine $10^{-1} \mathrm{M}$; colchicine, $10^{-4} \mathrm{M}$; 2,4-dinitrophenol, $10^{-3} \mathrm{M}$; ConA, $0.04 \mathrm{mg} / \mathrm{ml} . \mathrm{NaN}_{3}$ and 2,4-dinitrophenol are metabolic inhibitors. Colchicine reversibly disrupts microtubules, as does vinblastine. In addition, vinblastine induces crystallization of tubulin. ConA induces cross-linking of membrane components by binding to specific carbohydrate moieties of glycoproteins (12).

Sequence of immunolabeling. All reagents were diluted in cold minimum essential medium before use (Fig. 1). Metabolic inhibitors, when used, were present at the indicated concentration throughout incubations at 4 and $37^{\circ} \mathrm{C}$. Infected monolayers were washed several times with cold minimum essential medium and incubated for $1 \mathrm{~h}$ at $4^{\circ}$ with an anti-measles reagent [ $\operatorname{IgG}, \mathrm{F}\left(\mathrm{ab}^{\prime}\right) 2$, or Fab' fragments] at a concentration of $0.5 \mathrm{mg} / \mathrm{ml}$. Unreacted reagent was removed by washing. Monolayers were further incubated with a second reagent for $1 \mathrm{~h}$ at $4^{\circ} \mathrm{C}$ either at this stage or after fixation. This reagent was either labeled PrA (coupled to peroxidase or radioiodinated) or goat anti-human Fab IgG. After several washes with cold minimum essential medium, cells which were incubated with one or two reagents at $4^{\circ} \mathrm{C}$ were shifted to $37^{\circ} \mathrm{C}$ for 0 to $24 \mathrm{~h}$. When ${ }^{125}$ I-labeled PrA was used as a second reagent, medium was collected at the end of incubation at $37^{\circ} \mathrm{C}$, and its radioactivity was assayed in a gamma counter.

At the end of all experiments, monolayers were washed and fixed for $5 \mathrm{~min}$ in $1 \%$ formaldehyde in 0.1 $\mathrm{M}$ cacodylate buffer, $\mathrm{pH}$ 7.4. When the second reagent had been omitted before fixation, it was applied to fixed cells for $1 \mathrm{~h}$ at $20^{\circ} \mathrm{C}$. Finally, if a third incubation was required to detect the $\mathrm{Ag}$ - $\mathrm{Ab}$ complexes, 
it was always performed after fixation. Cells which had been incubated with PrA-peroxidase were reacted for $10 \mathrm{~min}$ at room temperature with the substrate for the enzyme $\left(1 \% \mathrm{H}_{2} \mathrm{O}_{2}\right)$ and $0.5 \mathrm{mg}$ of diaminobenzidine per $\mathrm{ml}$ in phosphate-buffered saline (7). Monolayers were then processed for autoradiography or TEM or SEM studies.

Autoradiography. Cover slips were dipped in nuclear type NTB 2 emulsion (Kodak, Rochester, N.Y.) and exposed for 3 to 15 days at $4{ }^{\circ} \mathrm{C}$. Slides were developed and fixed before being examined under a Zeiss Photoscope II equipped with a dark field.

TEM and SEM. Techniques for fixation, embedding, critical-point drying, and gold coating were described in the previous paper (20). However, in the present TEM study, giant cells were trimmed and thin sections were cut parallel to the monolayer.

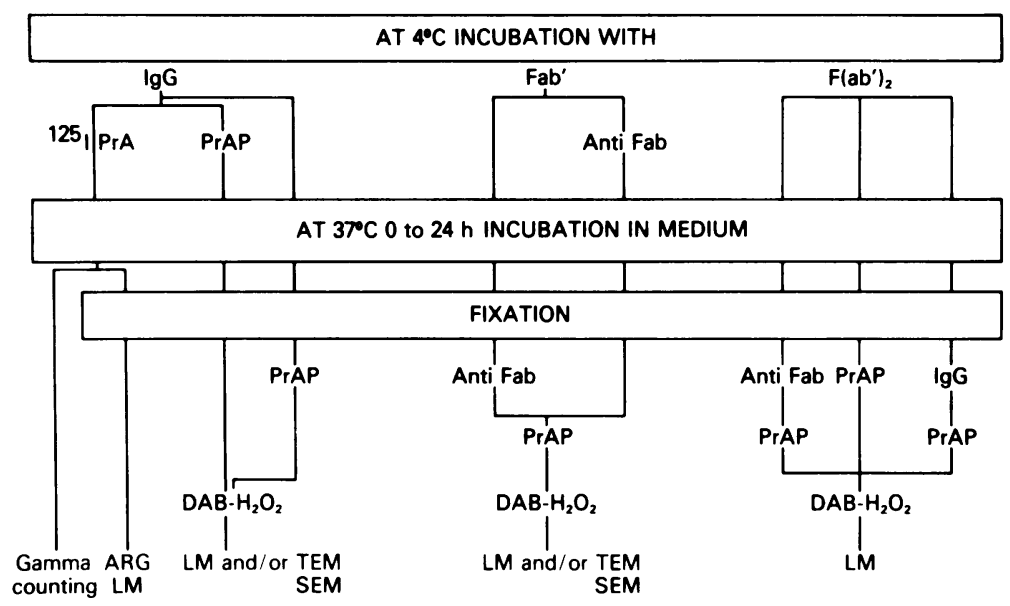

FIG. 1. Summary of the experimental conditions: treatment of living cells with measles virus. Abbreviations: ${ }^{n b}$ IPrA, iodinated PrA; PrAP, PrA coupled to peroxidase; DAB, diaminobenzidine; $A R G$, autoradiography; LM, light microscopy.

\section{Results}

At the low multiplicity of infection used throughout these experiments, 5 to 8 multinucleated cells with a diameter of approximately $800 \mu \mathrm{m}$ were dispersed on a 12-mm cover slip 3 days after infection with measles virus. The rest of the cover slip was covered with mononucle-ated Vero cells. All observations reported here were made on syncytia.

Distribution of measles virus antigens on the surface of giant cells after incubation at $4{ }^{\circ} \mathrm{C}$ (zero time). When living cells were incubated in the cold with anti-measles reagents, Ag-Ab complexes formed on the cell surface. These complexes could be detected by immu-noperoxidase or by autoradiography with labeled PrA. With either technique the label was shown to be evenly distributed over the cell surface with each of the anti-measles reagents [Fab', F(ab') $)_{2}$ IgG of both donors] (Fig. 2a, 3, and 4b). Thin sections through syncytia and high-magnification scanning electron micrographs of their entire surfaces revealed virus-specific label on smooth areas of the cell plas-malemma as well as on microvilli and viral buds (Fig. 3 and 4b). No label was observed inside the cell. Unlabeled cells in SEM show numerous twisted strands in identical areas (Fig. 4a).

Three types of control experiments indicate that the surface labeling was specific for measles virus antigens. First, uninfected Vero cells were not stained after treatment with anti-measles reagents. Second, infected cells were not stained by a serum with no anti-measles virus antibodies. Third, binding through a putative Fc receptor was excluded because anti-measles $F\left(a b^{\prime}\right)_{2}$ and $F a b^{\prime}$ induced a pattern of staining similar to that obtained with intact IgG. Moreover, preincubation of the cells with Fab' fragments prevented subsequent binding of $\mathrm{IgG}$. 
Redistribution and fate of measles Ag-Ab complexes during 24-h incubation at $37{ }^{\circ} \mathrm{C}$. Infected cells preincubated with anti-measles reagents in the cold were thoroughly washed and shifted to $37^{\circ} \mathrm{C}$ for various periods of time. As a result of this incubation at $37^{\circ} \mathrm{C}$, label was redistributed along the membrane and eventually was also found inside the cell and in the culture medium. By 5 min after the temperature shift to $37^{\circ} \mathrm{C}$, cells preincubated with anti-measles IgG and treated with labeled PrA after fixation showed clusters of label indicating a redistribution of $\mathrm{Ag}-\mathrm{Ab}$ complexes. This clustering was enhanced if a second cross-linking reagent, $\operatorname{PrA}$, was applied to cells before shifting to $37^{\circ} \mathrm{C}$, rather than after fixation.

After $1 \mathrm{~h}$ at $37^{\circ} \mathrm{C}$, immunoperoxidase staining, as well as autoradiography, showed a patchy distribution of surface label (Fig. 2b and 5a). TEM and SEM showed that smooth areas of the cell surface were now devoid of label, whereas folds, villi, and budding viruses were strongly labeled and grouped together (Fig. 5a and b). Thus, anti-measles IgG induced redistribution of antigen, as well as clustering of folds and villi.

After $3 \mathrm{~h}$ at $37^{\circ} \mathrm{C}$, the label was generally confined to very few clusters, leaving the periphery and the center of the syncytial membrane virtually free of label. These clusters often assumed the shape of a ring (Fig. 2c). Clustering of the label in a cap was occasionally observed (Fig. 6a).

After longer periods of incubation at $37^{\circ} \mathrm{C}$ ( 3 to $24 \mathrm{~h}$ ), the amount of surface label decreased considerably. Smooth and protruding areas of the surface became more randomly dis-tributed as seen in cells immunolabeled in the cold (compare Fig. 3 with Fig. 7). In autoradi-ographs, the number of silver grains on giant cells progressively decreased with time. Identical patterns of redistribution were observed when infected cells were incubated with $\mathrm{F}\left(\mathrm{ab}^{\prime}\right)_{2}$ followed by anti-Fab IgG and PrAperoxidase (Fig. 1).

After $24 \mathrm{~h}$ at $37^{\circ} \mathrm{C}$, the morphology of the cell was identical to that of unincubated cells except that some label was still present. When cells were reincubated with anti-measles IgG and PrA-peroxidase, diffuse and intense label of the giant cell surface reassembled the pattern obtained at zero time (Fig. 8). Viral antigens had thus been reinserted into the giant cell membrane, while clearing of Ag-Ab-PrA complexes had occurred.

(i) Endocytosis. At zero time, no label was seen in the cytoplasm. In contrast, after 1 to $3 \mathrm{~h}$ at $37^{\circ} \mathrm{C}$, an increasing number of phagocytic vacuoles containing peroxidase activity (presumably containing AgAb complexes) was detected by TEM (Fig. 6b). At this stage, some label was also occasionally found in residual bodies (Fig. 6b, inset). Phagocytic vacuoles still contained label after $24 \mathrm{~h}$ at $37^{\circ} \mathrm{C}$ (Fig. 7).

(ii) Release. In contrast to cell-associated radioactivity, which decreased with time, radioactivity released into the medium progressively increased; $26 \%$ of the cell-bound radioactivity was released after $15 \mathrm{~min}$ at $37^{\circ} \mathrm{C}$, and $88 \%$ was released after $24 \mathrm{~h}$ (Table 1 ).

Effect of drugs. Sodium azide, 2,4-dinitro-phenol, and high doses of ConA did not interfere with either binding or patching, but prevented further redistribution and ring formation. Treatment with vinblastine or colchicine had the same effect.

Effect of anti-measles Fab' fragments. To determine whether redistribution of measles virus Ag-Ab complexes had been triggered by the cross-linking properties of anti-measles virus IgG, Fab' fragments were prepared from an original batch of IgG and applied to infected cells. 

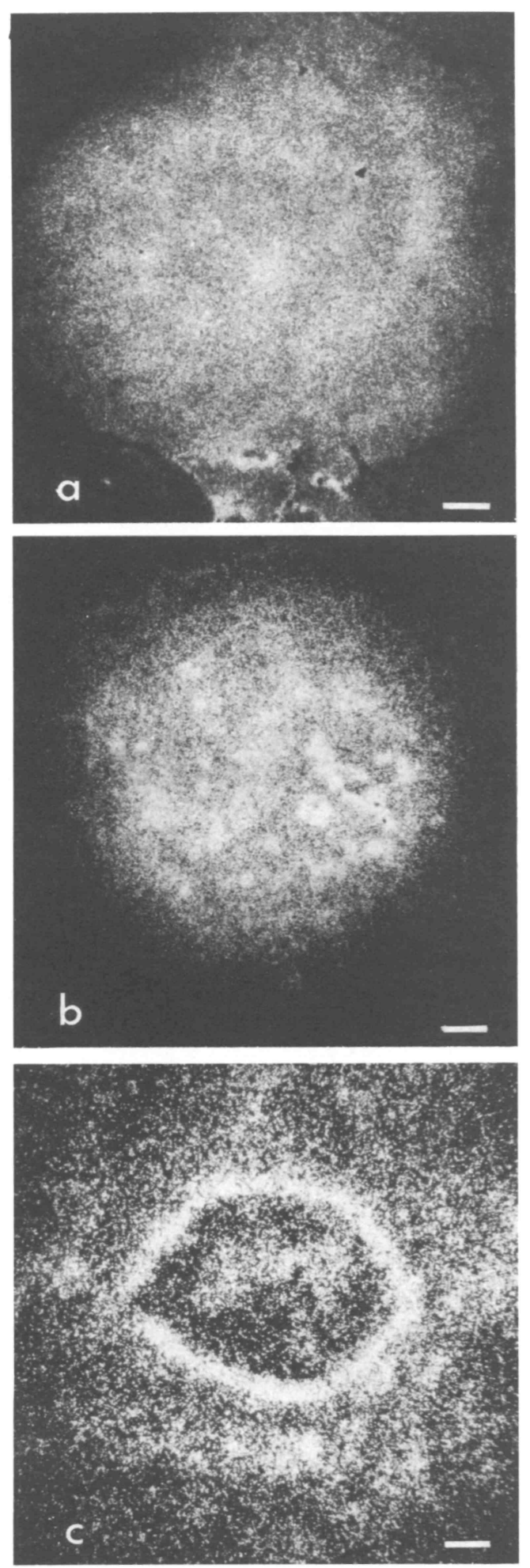

FIG. 2. Dark-field autoradiographs of monolayers of Vero cells infected with measles virus. Comparison between patterns of label obtained after treatment of infected cells with anti-measles IgG and ${ }^{125}$ I-labeled PrA at $4^{\circ} \mathrm{C}(a)$ and after further incubation at $37^{\circ} \mathrm{C}$ for $1 \mathrm{~h}(\mathrm{~b})$ and $3 \mathrm{~h}(\mathrm{c})$. In (a), grains are distributed homogeneously on the giant cell surface, whereas they are clustered into patches after $1 \mathrm{~h}$ at $37^{\circ} \mathrm{C}(\mathrm{b})$. Longer incubation $(3 \mathrm{~h})$ at $37^{\circ} \mathrm{C}$ resulted in an intense clustering of grains in a ring around the center of a giant cell (c). Bar $=100 \mu \mathrm{m}$. 


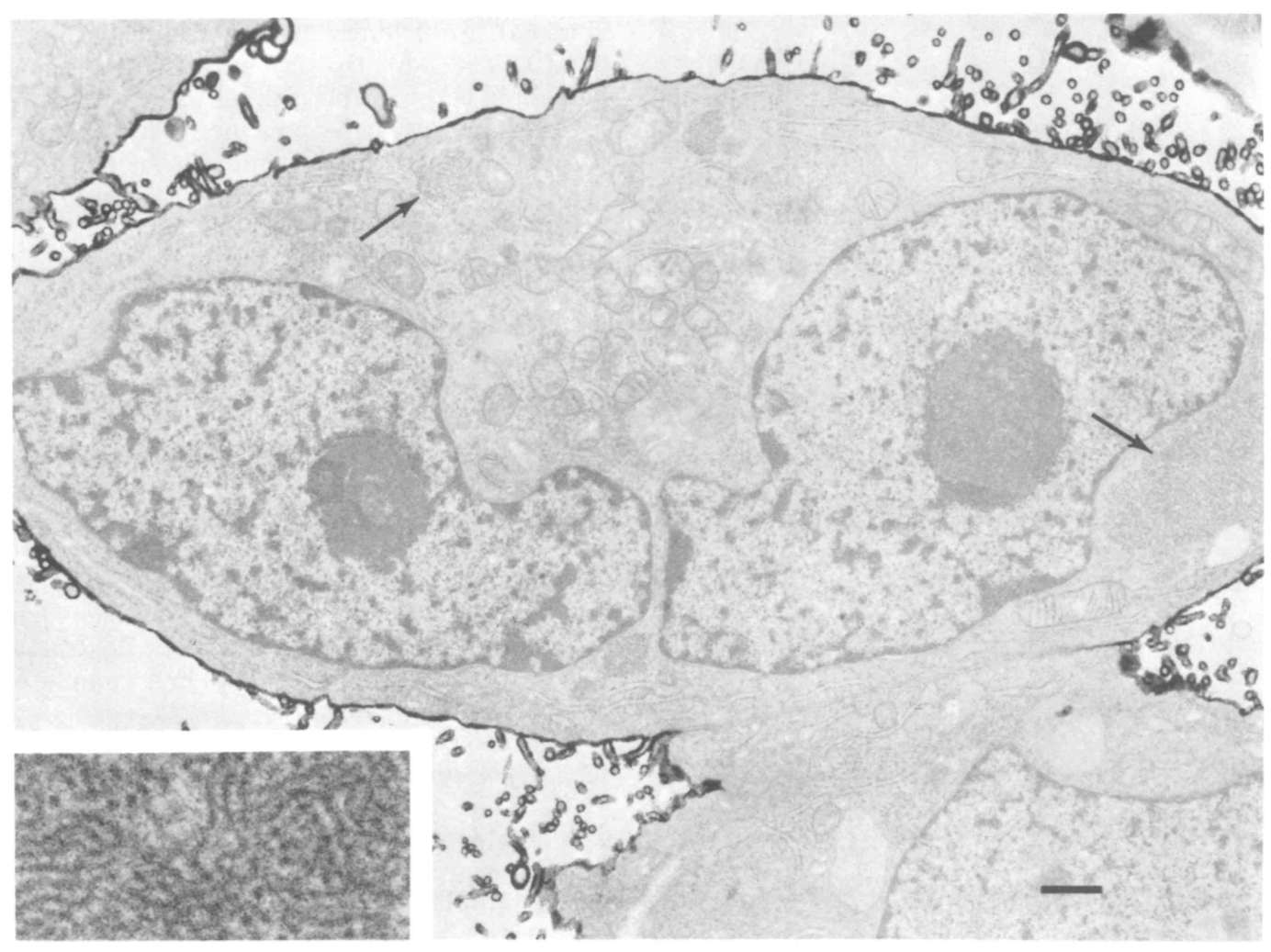

FIG. 3. Transmission electron micrograph of part of a syncytium. Serial sections showed a diffuse pattern of label on the giant cell surface treated at $4^{\circ} \mathrm{C}$ with anti-measles IgG and PrA-peroxidase. Black label is homogeneously distributed on the plasma membrane, which is covered with scattered villi. Several viral inclusions are seen in the cytoplasm (arrows). The inset shows that these inclusions are made of typical nucleocapsids surrounded by a granular coat. No counterstain with heavy metals. Bar $=1 \mu \mathrm{m}$. Inset, $X 32,000$.

A diffuse staining was obtained. No clustering of viral antigen-Fab' fragment complexes was observed, even after prolonged incubation at $37^{\circ} \mathrm{C}$. Moreover, during the 24-h period of observation, no significant clearing of viral antigen-Fab' fragment complexes seemed to occur. Labeling was indeed qualitatively and quantitatively similar at the beginning and the end of the incubation period. In addition, no evidence of either patching or endocytosis was found with either SEM or TEM. However, patching and ring formation were observed when a divalent reagent (anti-Fab IgG) was reacted with Fab'-treated living cells before incubation at $37^{\circ} \mathrm{C}$.

Redistribution of nonviral membrane components on giant cells. To determine whether ring formation was a pattern of redistribution specific to the type of cells studied or to measles virus antigens, similar experiments were performed with sera directed against normal membrane components of Vero cells. Mon-onucleated and giant cells treated with rabbit antiserum to Vero cells and ${ }^{125}$ I-labeled $\operatorname{PrA}$ at $4{ }^{\circ} \mathrm{C}$ were labeled in a homogeneous way. When cells were shifted to $37^{\circ} \mathrm{C}$, patch formation was detected after $5 \mathrm{~min}$. These patches progressively coalesced and formed a paracentral ring on giant cells after 45 min, as seen in virus-infected cells treated with viral antibody under similar conditions. Clearing was very rapid; no silver grains were observed in autoradiographs after $3 \mathrm{~h}$ at $37^{\circ} \mathrm{C}$.

\section{Discussion}

Antigenic sites detected on measles virus-induced giant cells incubated at $4^{\circ} \mathrm{C}$ with human antiviral $\mathrm{IgG}$ and labeled PrA were homogeneously distributed on the cell surface. After monolayers were shifted to $37^{\circ} \mathrm{C}, \mathrm{Ag}-\mathrm{Ab}$ complexes were redistributed along the cell membrane. Progressive clearing of these complexes occurred through shedding and endocytosis while viral antigens reappeared on the giant cell membrane. This sequence of events, which involves a dramatic cell surface remodeling, is 
temperature dependent and is only triggered by $\operatorname{IgG}$ or $\mathrm{F}\left(\mathrm{ab}^{\prime}\right)_{2}$ fragments but not by Fab' fragments.

The redistribution of Ag-Ab complexes on the giant cell membrane occurred in two stages which had different metabolic requirements.
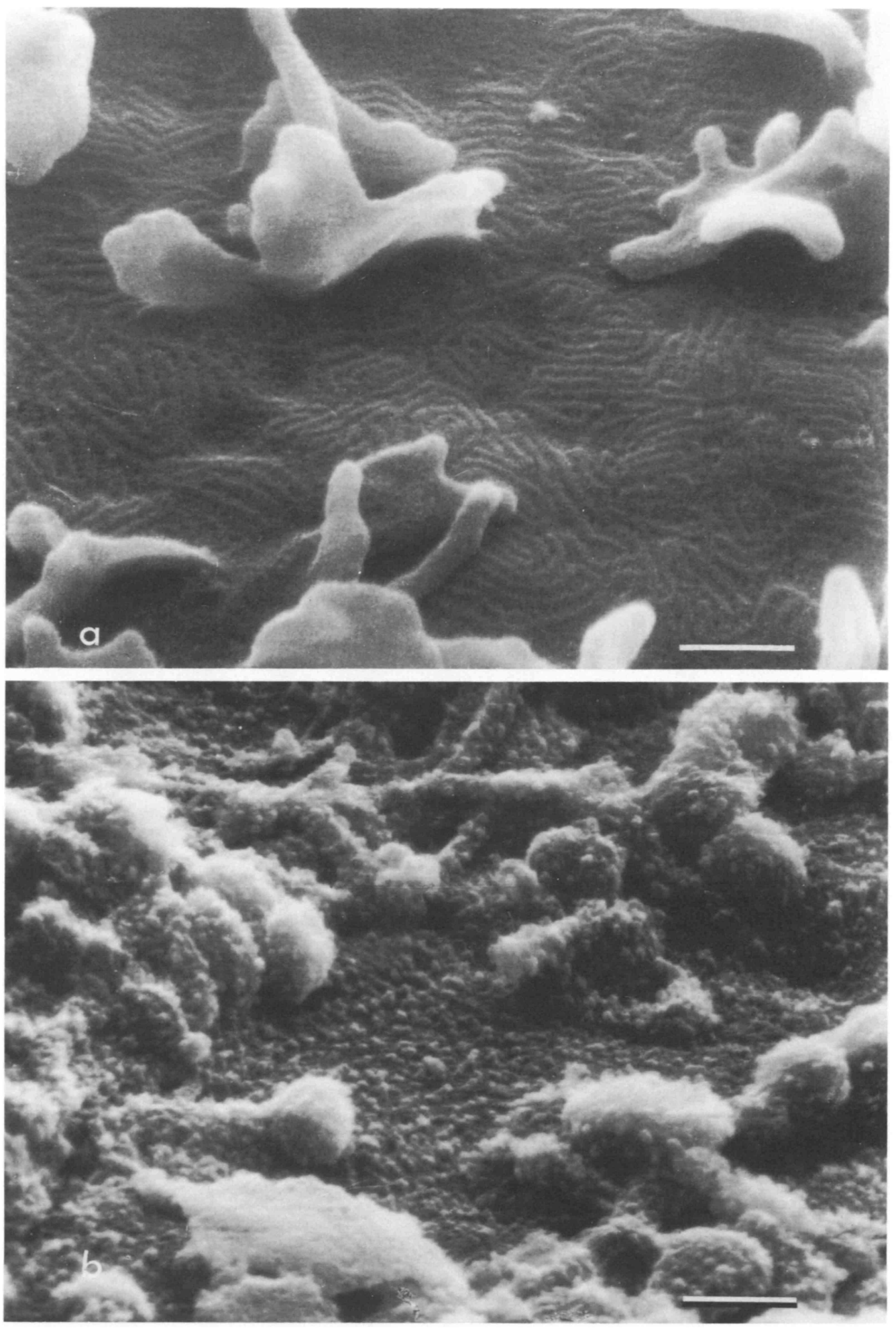

FIG. 4. High-magnification scanning electron micrograph of the center of a giant cell before (a) and after (b) immunoperoxidase labeling of living cells at $4^{\circ} \mathrm{C}$. In (a), the cell membrane is covered with twisted strands which are virus-induced structures lying over nucleocapsids. As in Fig. 3, ruffles and microvilli are randomly distributed on the plasma membrane. In (b), the peroxidase reaction product, 
which appears as black label in TEM, is visualized in SEM as granules 20 to $30 \mathrm{~nm}$ in size. These granules of label are evenly distributed on the membrane, ruffles, and villi. Bar $=0.5 \mu \mathrm{m}$.
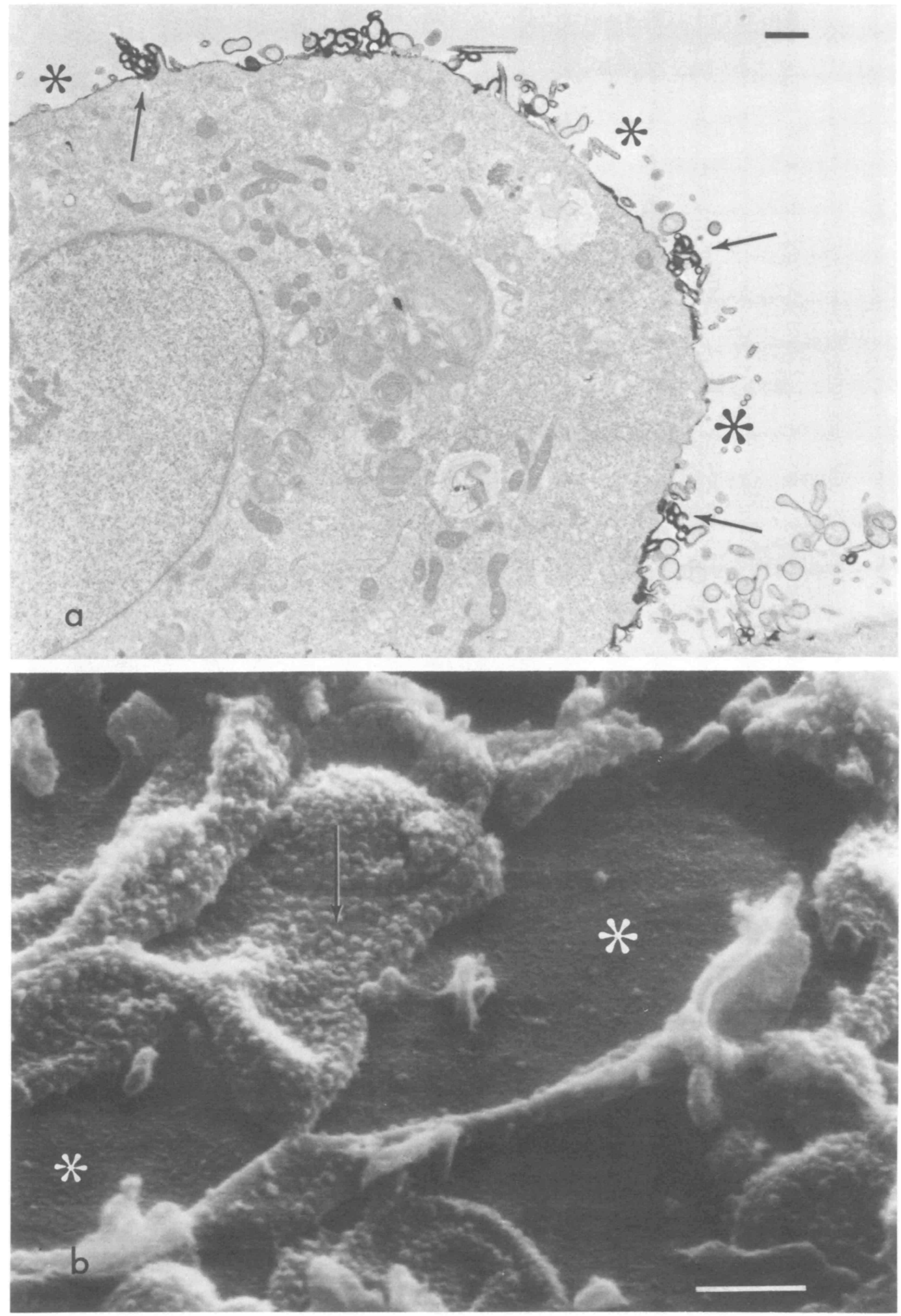

FIG. 5. Transmission (a) and scanning (b) electron micrographs both reveal similar changes in distribution of label on giant cells immunolabeled at $4^{\circ} \mathrm{C}$ and further incubated for $1 \mathrm{~h}$ at $37^{\circ} \mathrm{C}$ as in Fig. 2b. In contrast to the diffuse pattern of label observed at $4{ }^{\circ} \mathrm{C}$ (Fig. 3 and $4 b$ ), label is now restricted to viral buds, ruffles, and villi (arrows) which are clustered in some areas of the membrane. Flat surfaces are completely devoid of label (asterisks), (a) Bar $=1 \mu \mathrm{m}$; (b) bar $=0.5 \mu \mathrm{m}$. 

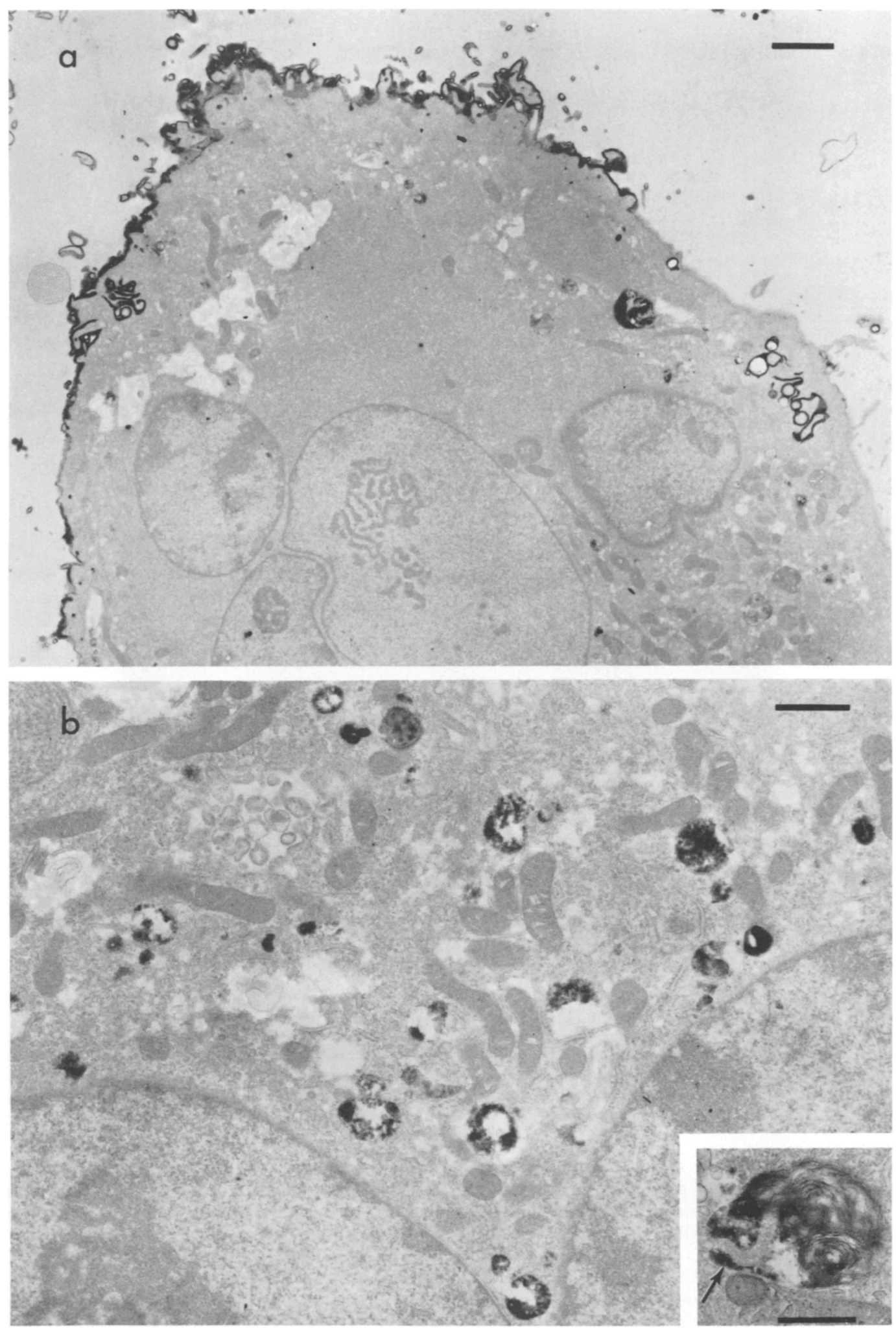

FIG. 6. At 3 h after shifting cells to $37^{\circ} \mathrm{C}$, peroxidase label is concentrated on the membrane in a cap $(a)$ and found within the cytoplasm of giant cells $(b)$. In (a), numerous labeled villi and folds are concentrated in the cap, whereas adjacent membrane is smooth and cleared of label. In $(b)$, numerous vacuoles at various distances from the surface contain black label. Serial sections showed that these vacuoles were not infoldings of the labeled cell surface. The inset shows label (arrow) in a residual body which also contains osmiophilic lamellae, (a) Bar $=2 \mu \mathrm{m}$; (b) bar $=0.5 \mu \mathrm{m}$. 

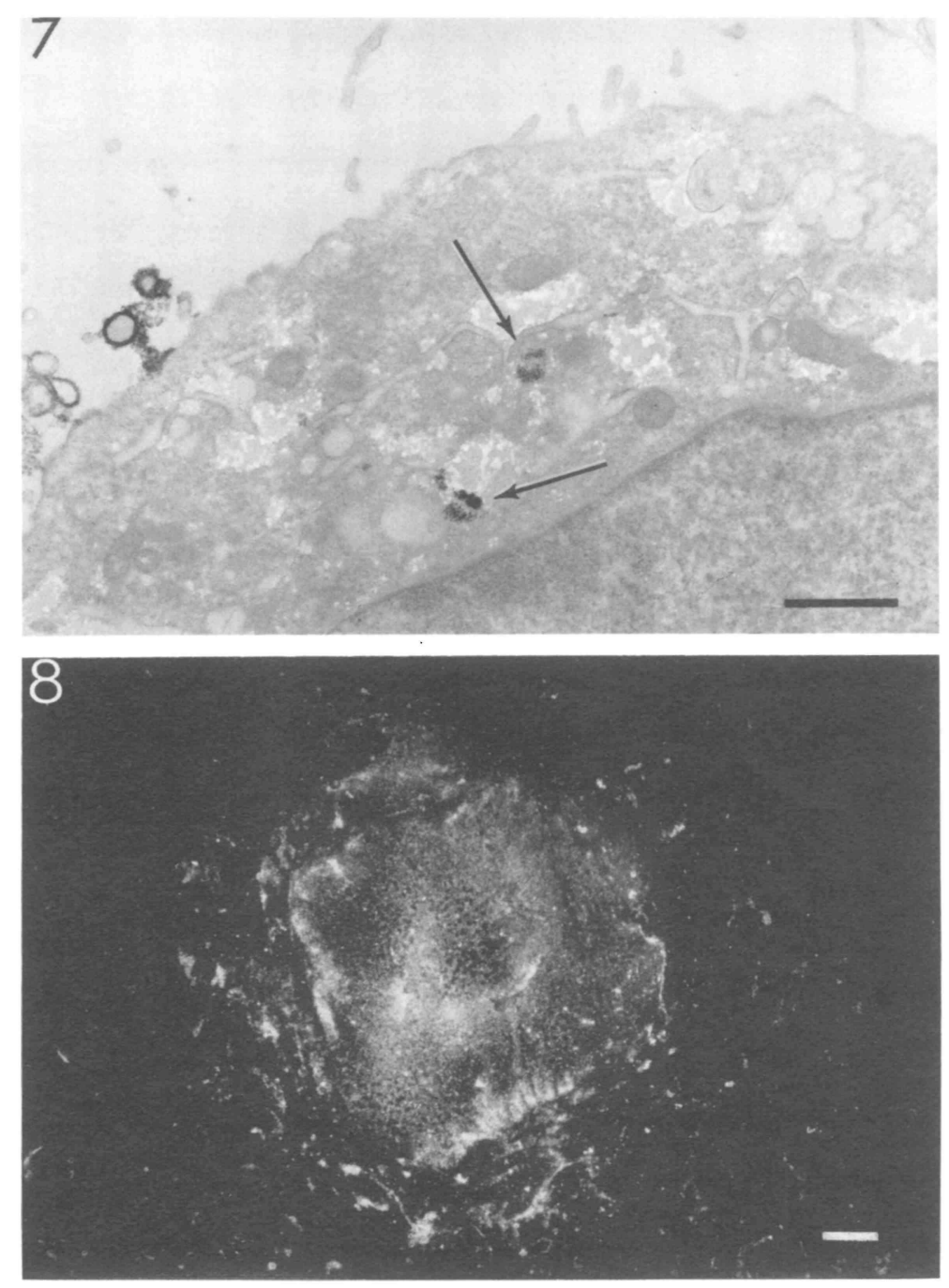

FIG. 7. After a $24 \mathrm{~h}$ incubation at $37^{\circ} \mathrm{C}$, giant cells are almost devoid of peroxidase label and display scattered villi as at zero time (see Fig. 3). Some label is apparently detached from the cell and inside vacuoles (arrows). Bar $=1 \mu \mathrm{m}$.

FIG. 8. Dark-field light micrograph of infected Vero cells immunolabeled at $4^{\circ} \mathrm{C}$ and then incubated for $24 \mathrm{~h}$ at $37^{\circ} \mathrm{C}$. At the end of this incubation, peroxidase label was no longer detected on the plasma membrane, as shown in Fig. 7. However, a second treatment with anti-measles IgG and PrA coupled to peroxidase revealed a diffuse pattern of label as observed before incubation at $37^{\circ} \mathrm{C} . \mathrm{Bar}=100 \mu \mathrm{m}$.

The early stage of redistribution, which consisted in patch formation, required at least one layer of a multivalent reagent, but no metabolic energy, since it was observed in the presence of $\mathrm{NaN}_{3}$ or 2,4dinitrophenol. A second pattern of redistribution, which shared many characteristic features with cap formation, was observed with time. It followed patching, required a divalent ligand, and was sensitive to metabolic inhibitors and to high concentrations of ConA.

Redistribution of viral antigen on the giant cell surface had peculiar features. Typical caps were rarely observed. Instead, label was often concentrated in a ring located around the center of the giant cells where lysis later occurred. Events responsible for central lysis of the giant cell might prevent further redistribution so that caps rarely formed. Ring formation has also been shown in measles virus-induced giant cells labeled with monkey erythrocytes (20). In this case, SEM clearly showed monkey erythrocytes on the giant cell surface surrounding a central flat area. 
TABLE 1. Release of radioactivity into the medium

\begin{tabular}{ll}
\hline Time interval $^{\mathrm{a}}$ & $\begin{array}{l}\text { \% of counts recovered in } \\
\text { the culture medium }\end{array}$ \\
\hline $0 \quad \ldots \ldots \ldots$. & 1 \\
\hline 15 min ..... & 26 \\
\hline 30 min..... & 28 \\
\hline 60 min.... & 36 \\
\hline $3 \mathrm{~h} \ldots \ldots .$. & 52 \\
\hline $24 \mathrm{~h} \ldots \ldots .$. & 88 \\
\hline
\end{tabular}

${ }^{a}$ Timed from the start of incubation at $37^{\circ} \mathrm{C}$ to fixation of cells.

Similarity between the pattern of redistribution of hemadsorbing sites and that of labeled viral antigens suggests that the ring pattern corresponds to surface label. Albertini and Anderson have shown that patches of lectin-receptor complexes move centripetally on the cell surface to form a ring and, with time, a single central cap (1). In other studies, however, rings have been shown to be due to endocytic vesicles within the cells (24). Interestingly, accumulation of Ag-Ab complexes in a ring on the giant cell surface could also be produced by antibody against nonviral membrane antigen. It thus appears that the peculiar pattern of redistribution of $\mathrm{Ag}-\mathrm{Ab}$ complexes on the measles virus-induced giant cell is characteristic of the giant cell itself rather than of the nature (host or viral) of the antigens studied.

Patches, rings, and caps identified in the light microscope were shown in the TEM to be made of strongly labeled villi, large folds of membrane, and viral buds contrasting with adjacent flat surfaces free of label. Thus, patching of Ag-Ab complexes appeared concomitantly with the grouping of large folds of labeled membranes which might precede shedding.

The present observations provide additional evidence that measles virus-coded proteins are able to move within the plane of the infected cell membrane. Membrane fluidity of virus-induced giant cells may, however, vary with the stage of fusion. For instance, during myoblast formation, a slight increase in membranal fluidity occurred before fusion, and a decrease was observed during postfusional differentiation (19). Lateral movements of measles antigens in the absence of any ligand can occur during viral bud formation (4) or during reinsertion of the viral hemagglutinin after its stripping by trypsin (5). In our system, however, the redistribution of measles antigens expressed on the giant cell surface required cross-linking by divalent antibody. Neither patching nor significant shedding was induced by monovalent Fab', and cell surface remodeling was never detected with TEM or SEM after Fab' treatment. Thus, cross-linking of measles antigens may be a prerequisite for clearing of Ag- $\mathrm{Ab}$ complexes.

Previous studies have shown that cells were able to clear Ag-Ab complexes through both shedding and endocytosis. Lymphocytes cleared most of their surface complexes through endo-cytosis, whereas in measles virus-infected HeLa cells shedding was the major event $(2,11,17)$. Endocytosis has also been described in influenza virus-infected HeLa cells (23). In our system, the relative importance of each process was difficult to assess because some material might have first been endocytosed and then released into the medium. However, the existence of labeled budding and free virions suggested that direct shedding into the extracellular space had occurred.

Structural events related to prolonged antibody treatment of measles virus-infected cells should now be analyzed and compared with the short-term effect. Various studies have indeed shown that anti-measles 
serum, in the absence of complement, can lead to attenuation of the virus and to chronic infection (6, $13,15,22)$.

\section{Acknowledgments}

We are indebted to R. J. Hooghe for his critical and extensive help throughout the course of this investigation. We are grateful to S. Rudikoff for his valuable help in preparing the Fab' fragments. We also thank W. Bonner, P. A. Henkart, F. Loor, H. McFarland, J. Schlessinger, and J. L. Sever for critical reading of the manuscript. The technical help of K. Worthington is gratefully acknowledged. F. M. Reid skillfully typed the manuscript.

E.L.H.-P. and B.R. were Visiting Fellows of the Fogarty International Center while performing this work. M.D.-D. is Visiting Scientist at the National Institutes of Health.

\section{References}

[1]. Albertini, D. F., and E. Anderson. 1977. Microtubule and microfilament rearrangement during capping of concanavalin A receptors on cultured ovarian granulosa cells. J. Cell Biol. 73:111-127.

[2]. de Petris, S. 1977. Distribution and mobility of plasma membrane components on lymphocytes, p. 643-728. In G. Poste and G. L. Nicolson (ed.), Dynamic aspects of cell surface organization, vol. 3. North-Holland Publishing Co., Amsterdam.

[3]. Dubois-Dalcq, M., H. McFarland, and D. McFarlin. 1977. Protein A-peroxidase: a valuable tool for the localization of antigens. J. Histochem. Cytochem. 25: 1201-1206.

[4]. Dubois-Dalcq, M., and T. S. Reese. 1975. Structural changes in the membrane of Vero cells infected with a paramyxovirus. J. Cell Biol. 67:551-565.

[5]. Ehrnst, A., and K. G. Sundqvist. 1975. Polar appearance and nonligand induced spreading of measles virus hemagglutinin at the surface of chronically infected cells. Cell 5:351-359.

[6]. Gould, J. J., and J. D. Almeida. 1977. Antibody-modification of measles "In Vitro" infection. J. Med. Virol. 1:111-117.

[7]. Graham, R. C, and M. J. Karnovsky. 1966. The early stage of absorption of injected horseradish peroxidase in the proximal tubules of mouse kidney: ultrastructural cytochemistry by a new technique. J. Histochem. Cytochem. 14:291-302.

[8]. Greenwood, F. C, W. M. Hunter, and J. S. Glover. 1963. The preparation of ${ }^{131}$ I-labelled human growth hormone of high specific radioactivity. Biochem. J. 89: 114-123.

[9]. Joseph, B. S., and M. B. A. Oldstone. 1974. Antibody-induced redistribution of measles virus antigens on the cell surface. J. Immunol. 113:1205-1209.

[10]. Joseph, B. S., and M. B. A. Oldstone. 1975. Immunologic injury in measles virus infection. II. Suppression of immune injury through antigenic modulation. J. Exp. Med. 142:864-876.

[11]. Lampert, P., B. S. Joseph, and M. B. A. Oldstone.1975. Antibody-induced capping of measles virus antigens on plasma membrane studied by electron microscopy. J. Virol. 15:1248-1255.

[12]. Loor, F. 1977. Structure and dynamics of the lymphocyte surface, in relation to differentiation, recognition and activation. Prog. Allergy 23:1-153. 
[13]. Minagawa, T. 1971. Studies on the persistent infection with measles virus in HeLa cells. I. Clonal analysis of cells of carrier cultures. Jpn. J. Microbiol. 15:325-331.

[14]. Natvig, J. B., and M. W. Turner. 1971. Localization of Gm markers to different molecular regions of the Fc fragment. Clin. Exp. Immunol. 8:685-700.

[15]. Norrby, E. 1967. A carrier cell line of measles virus in Lu 106 cells. Arch. Gesamte Virusforsch. 20:215-224.

[16]. Oldstone, M. B. A., and A. Tishon. 1978. Immunologic injury in measles virus infection. IV. Antigenic modulation and abrogation of lymphocyte lysis of virus-infected cells. Clin. Immunol. Immunopathol. 9:55-62.

[17]. Perrin, L. H., and M. B. A. Oldstone. 1977. The formation and fate of virus antigen-antibody complexes. J. Immunol. 118:316-322.

[18]. Phillips, E. R., and J. F. Perdue. 1976. The dynamics of antibody-induced redistribution of viral envelope antigens in the plasma membranes of avian tumor virus-infected chick embryo fibroblasts. J. Cell Sci. 20: 459-477.

[19]. Prives, J., and M. Shinitzky. 1977. Increased membrane fluidity precedes fusion of muscle cells. Nature (London) 268:761-763.

[20]. Rentier, B., E. L. Hooghe-Peters, and M. Dubois-Dalcq. 1978. Electron microscopic study of measles virus infection: cell fusion and hemadsorption. J. Virol. 28:567-577.

[21]. RudikofT, S., M. Potter, D. M. Segal, E. A. Padlan, and D. R. Davies. 1972. Crystals of phosphorylcholine-binding Fab-fragments from mouse myeloma proteins: preparation and X-ray analysis. Proc. Natl. Acad. Sci. U.S.A. 69:3689-3692.

[22]. Rustigian, R. 1966. Persistent infection of cells in culture by measles virus. II. Effect of measles antibody on persistently infected HeLa sublines and recovery of a HeLa clonal line persistently infected with incomplete virus. J. Bacteriol. 92:1805-1811.

[23]. Rutter, G., and K. Mannweiler. 1976. Antibody-induced redistribution of virus antigens on the surface of influenza virus-infected cells. J. Gen. Virol. 33:321-332.

[24]. Schlessinger, J., Y. Schechter, M. C. Willingham, and I. Pastan. 1978. Direct visualization of binding, aggregation, and internalization of insulin and epidermal growth factor on living fibroblast cells. Proc. Natl. Acad. Sci. U.S.A. 75:2659-2663.

[25]. Schreiner, G. F., and E. R. Unanue. 1976. Membrane and cytoplasmic changes in B lymphocytes induced by ligand-surface immunoglobulin interaction. Advances Immunol. 24:37-165.

[26]. Sever, J. L. 1962. Application of a microtechnique to viral serological investigations. J. Immunol. 88:320-329.

[27]. Sever, J. L., A. C. Ley, F. Wolman, B. M. Caplan, P. W. Crockett, and H. C. Turner. 1964. Utilization of disposable plastic plates with a serologic microtechnique. Am. J. Clin. Pathol. 41:167170.

[28]. Sober, H. A., F. J. Gutter, M. M. Wyckoff, and E. A. Peterson. 1956. Chromatography of proteins. II. Fractionation of serum proteins on anion-exchange cellulose. J. Am. Chem. Soc. 78:756763. 